\title{
TWO EARLY MEDIEVAL KNIVES WITH BONE HANDLES FROM NITR A*
}

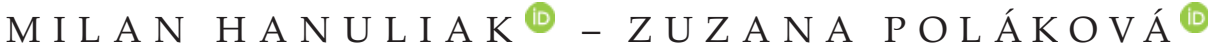

\begin{abstract}
The aim of the study is to enlighten the circumstances of occurrence of knives with bone handle at the territory of Nitra in the $9^{\text {th }} \mathrm{c}$. and to draw the attention to the insufficiency of them at the remaining regions of Slovakia. Results of some of the analysis suggested that these specimens belong to the more luxurious artefacts, which could have been used to show higher rank of individuals with considerable property. Real causes for restricted occurrence of such artefacts are not known. The cause of this may have been that other possibilities were also used for this purpose.
\end{abstract}

Keywords: Slovakia, Great Moravian Period, knife with bone handle, bone processing, social problem.

\section{INTRODUCTION}

The items which are preferentially evaluated in this article come from two graves dug at burial sites used in the Great Moravian period in the territory of historical Nitra. Besides their specifically designed handles, they differ from other knives also found in the environment of contemporary necropoli with other details and components incorporated in the relevant elements of the burial rite. Although no significant differences occur in the recorded find contexts, the circumstances of their existence and association with the social sphere and other bone and antler artefacts should not be ignored.

\section{BASIC INFORMATION}

In order to express important information, both exemplars of knives will be described in detail in this part. The first knife was discovered in 1976 in grave 6 excavated on the periphery of a large burial ground located in the part of the town called Dolné Krškany. It was a rescue excavation, since this area was endangered by the construction of the Mier factory, or Nábytkáreň, a furniture making factory (Fig. 1: 1; Hanuliak/Chropovský 2019).

Thanks to the favourable find context, a numerous range of less frequent expressions was discovered in the above mentioned grave. Attention is called mainly by the knife itself, with its bone handle covered in engraved decoration. The part of the knife in question is not a monolithic cylinder. It consists of two strip slabs, $1.6 \mathrm{~cm}$ wide. These slabs with arcuate profiles are attached to the knife's end part with an offset tang with three iron rivets. Their polished surface is decorated with at least six pairs of shallowly engraved concentric circles with diameter of $0.6 \mathrm{~cm}$ arranged in two parallel rows (Fig. 2: 1). The fragmentary state of the handle makes its detailed description difficult. The unknown circumstances leading to the break of the discussed part of the knife made of a firm iron tang covered with slabs are worth mentioning.

A higher social status of the buried middle-aged man (M mat; identified by M. Vondráková 1982) can be deduced from the excessively deep grave pit - up to $200 \mathrm{~cm}$ - and its calculated volume of $3.8 \mathrm{~m}^{3}$ (Hanuliak/Chropovský 2019, 289). The suggested social status corresponds not only with the completed shape of the large knife extended to $23.6 \mathrm{~cm}$ in total, but a wooden bucket with arcuate handle and three rings attached with cross-shaped fittings (Fig. 2: 2) is also important. Representatives with the above described components belong to reliable indicators of a higher social status of male individuals in the Great Moravian environment (Hanuliak 2019a, 45, 46).

Significant information should also include the location of grave 6 within the burial ground of group II, in which graves with valuable accompanying parameters are accumulated. Thus, the location of the knife in question placed in the middle of the body's chest by the survivors might also have its meaning. This unignorable position can be - with an acceptable portion of tolerance - indicated as

\footnotetext{
* The article is supported by project APVV-16-0449 called Medieval Nitra in material sources and project 2/0124/20 VEGA called Economy of the Middle Ages (6 $6^{\text {th }}-13^{\text {th }}$ centuries).
} 
a demonstrative expression of his importance in the local community. The lack of other graves with identical composition of determinative expressions confirms that it is a purely local custom not used by members of other communities. Considerations of unspecified impulses with ritual meaning (Profantová 2003, 85) are little persuasive in this case.

The suggested circumstance is only secondary. More attention should be focused on search for association between the processed collection of knives and the social status of individuals buried at other necropoli. Unfortunately, there are very few such cases. In Slovakia, their occurrence is limited to a single site formed also in the Early Medieval agglomeration of Nitra. Its area was documented in the cadastral area of Staré Mesto in 2018 (Fig. 1: 2). It occurred in the inner area of the Polygón polyfunctional complex, which was previously used as a market place complemented with small shops.

Results of the rescue excavation were influenced by the limited excavation potential reduced to the base parts of the structure's pillars' feet. We can only deduce from them that a knife was found in one of the six graves at a small burial ground. It is grave 2, where this artefact was deposited next to the right side of an adult individual's pelvis; the individual's sex has not been specified. The artefact's blade is terminated with a flat tang narrowed at the bottom. It reaches almost to the middle of the handle. The knife's length was thus extended to $24 \mathrm{~cm}$. Width of the bone slabs made from the tibia of an unidentified animal widened from $2.2 \mathrm{~cm}$ to $2.8 \mathrm{~cm}$ at the end of the handle. Their shape thus became trapezoidal and they were joined with three iron rivets. Their pale-yellow polished surface is covered in irregularly distributed engraved circles. Some of them are scattered, some make up clusters of two or three, exceptionally touching each other. The functional part of the blade, which is $10.8 \mathrm{~cm}$ long, is $2.2 \mathrm{~cm}$ wide (Fig. 2: 3). According to these dimensions, the described exemplar can be classified into tools which were able to cause severe wounds and were, thus, appreciated in fights. This circumstance together with its luxurious design makes this knife different from other knives from Great Moravian graves.

With regard to the complicated stratigraphic conditions and the limited extent of the rescue works, some complementary information on the grave pit and other artefacts from the grave goods was impossible to document. The effort to specify the social status of the buried individual encounters some problems. Structure of the burial ground used around the younger Great Moravian horizon cannot be outlined under such circumstances either. It is confirmed by two earrings with wire knots and

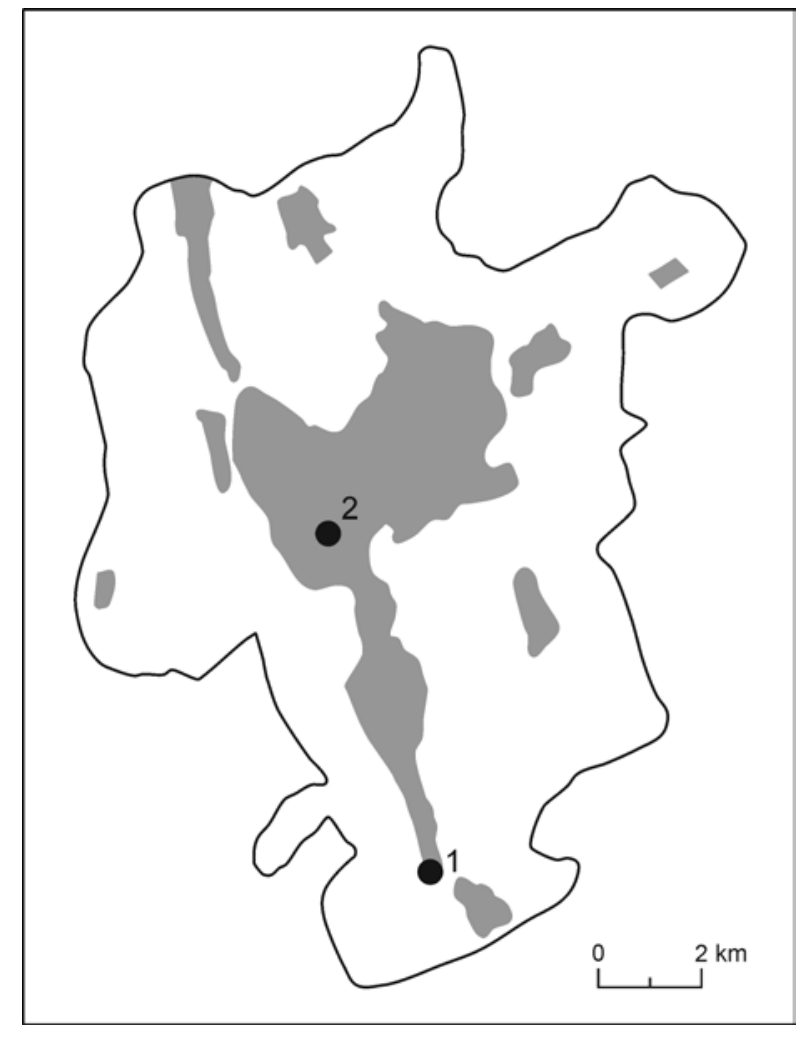

Fig. 1. The territory of historical Nitra in Great Moravian period. 1 - Dolné Krškany-Závod Mier; 2 - Staré MestoPolygón.

conical spiral pendant from bronze wire discovered near another disturbed skeleton. They allow us to attribute the local community an average social status at most (Hanuliak 2004, 160, 161). Location of its life territory in the more exposed part of Nitra's settlement agglomeration also sounds inspiring. This is also suggested by the short distance of the site in question from an important long-distance route. Its line leading from Constantinople crossed the historical area of Nitra and led to the Prague Basin across Moravia (Lukačka 2010, 283). Populations from the wider surroundings of the studied site could have also contributed to passive protection of the central part of the agglomeration (Fig. 1: 2). A small burial ground is also located there; it was studied in 2000 and 2001, on the courtyard of the nearby town marketplace (Bednár/Fottová 2003, 306, $307)$ formed in the early $10^{\text {th }} \mathrm{c}$. The relatedness of both sites is indicated also by contemporary settlement features documented at each one. The southernmost enclave of the agglomeration with a large burial ground in Dolné Krškany is represented by the above-mentioned knife with bone handle slabs from grave 6 classified in the older Great Moravian horizon and it also gains its relevance (Fig. 1: 1; Hanuliak 2019b, 84). 


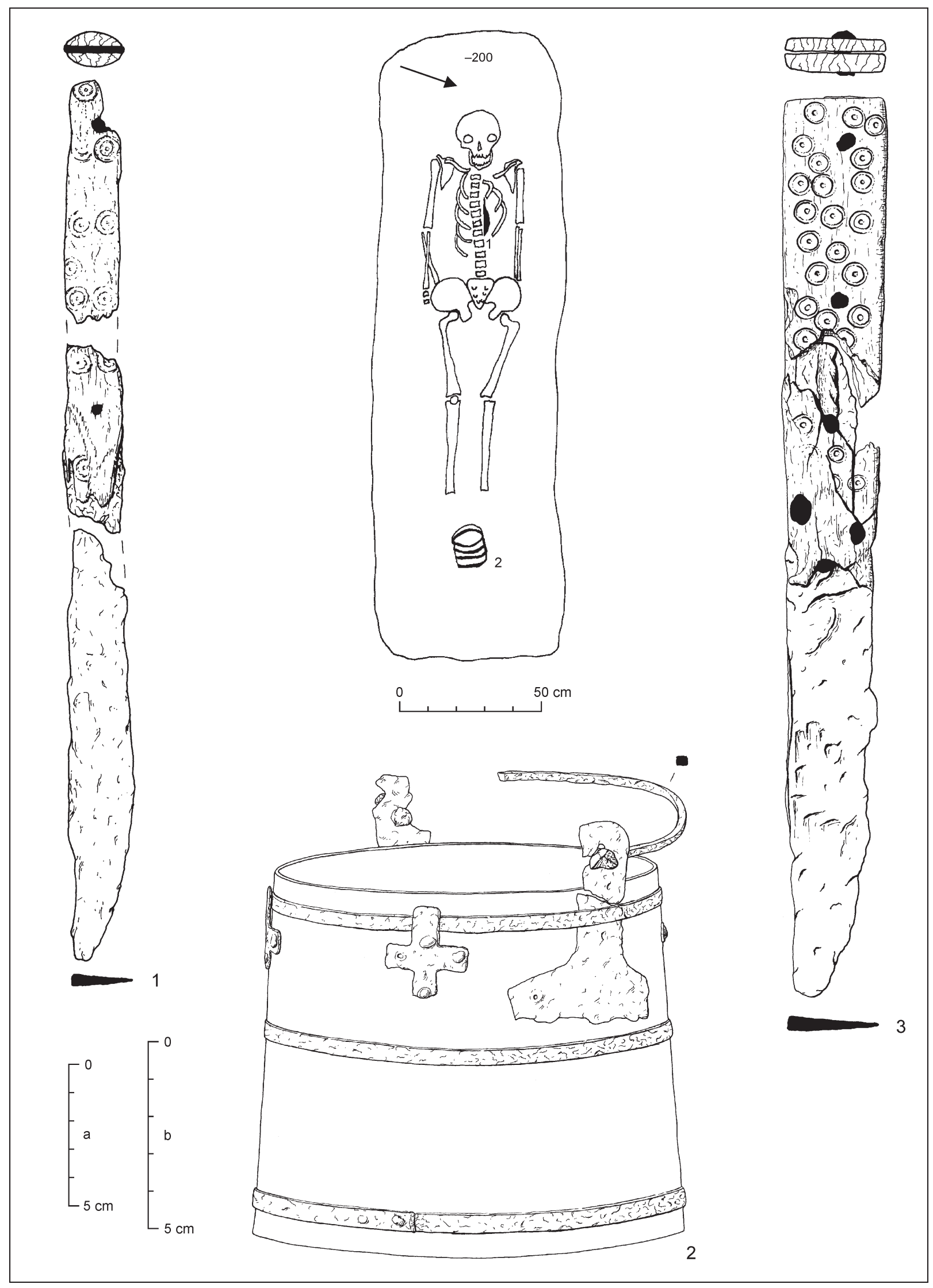

Fig. 2. 1, 2-Dolné Krškany-Závod Mier, plan and finds in grave 6; 3 - Staré Mesto-Polygón, find in grave 2. Scale: a - 2; $\mathrm{b}-1,3$. 


\section{INFORMATION ANALYSIS}

The currently evaluated pair of knives is interesting mainly with their handles with bone slabs with polished surfaces. The important fact is that it is not the most easily available wooden matter resistant to many negative influences from the surrounding environment but an undetermined bone material. Products made from it were not unknown in the Early Medieval central European environment (Hrubý 1957; Kaván 1958), although - compared to wooden artefacts - they were much less frequent. Despite this, the logically presumed versatility of use of wood cannot be confirmed more exactly, since it was totally decomposed in many find contexts. Here, we come across remains of wood petrified with corrosion on knife blades more often than on tangs in handles tooled from this material. As an illustration, we can mention the burial ground in Cakajovce with the highest number of knives, where handles made of maple, ash and apple tree wood were recorded in eight cases, while information on sheaths from maple wood comes from 16 graves (Rejholcová 1995, 45, 46).

Design of the handle slabs is another interesting aspect of this find. The fanciful design is multiplied with decorative motifs composed of transverse bands of engraved circles. The combination of these elements did not occur accidentally, without effort to intensify the aesthetic impression, which makes both representatives stand out in the numerous group of items of everyday use. Their transformation into luxurious products must have involved a verified process used in primary treatment of suitable bones, practical skills in production of semi-finished products, further modification and decoration of their surface and attaching the slabs to the end parts of knives.

Undoubtedly, successful application of working procedures was reflected in the increased economic value of such products which were available to the richer individuals from important central sites and their catchment areas. That is also why we do not come across adequate representatives in other regions in the eastern part of the Great Moravian territory - with the exception of historical Nitra. From this point of view, we should be finding such exemplars at the sites of the Moravian territory. The exemplars concentrated in the comparison collection, however, do not support the logically justified assumptions. Their absence in the most important hillfort of the Mikulčice centre from the site of Valy is, thus, surprising. More complex parts of deer antler slabs at this site come exclusively from features and the surrounding settlement layers. Undecorated as well as decorated exemplars often covered in concentric circles come from their collection (Kavánová 1995, 287, 288, pl. XL: 1-8, 10, 11). The last representative from feature 731 is almost identical with the handle of the knife discovered in grave 6 at the necropolis in Dolné Krškany with its size and applied decorative motifs (Fig. 2: 1). Other decorated handle slabs from grave 17 , feature 703 and 1223 (Kavánová 1995, 287, 288, pl. XL: 2, 4, 7) loosely resemble finds from Polygón with their overall decoration (Fig. 2: 3). Unlike the previous examples, grave 174 from the church cemetery of a magnate's farmstead in Břeclav-Pohansko has accompanying information of expected quality. An adult man was buried in an extra-large-grave pit, together with a long knife, a sword and spurs. With two razors, a key and a strike-a-light, there was a knife among his personal items. Its handle is decorated with three bands of concentric circles with the central points covering the whole surface (Kalousek 1971, 111-113).

Grave 180/AZ from the central necropolis at the site of Na valách belonging to the agglomeration in the vicinity of Staré Město is also very interesting. It is associated with a man of a very old age from the deep grave pit with almost absent grave goods. The only exception is a knife with precisely applied decorative motifs composed of transverse grooves, shaded bands, twists and circles (Hrubý 1955, 385, 386, fig. 12: 1a, b; pl. 35: 7). In other three graves, adult women were placed, averagely sunken, without any added goods. Among knives, an exemplar with total length of $24.7 \mathrm{~cm}$ from grave JP/156 at the Southern Bailey of Břeclav-Pohansko stands out. The slabs' surface is covered with two parallel bands of circles (Přichystalová/Kalová/Boberová 2019, 319, 395, pl. XLIV). Knives with undecorated bone slabs deposited next to left elbows and - in one case - across the left pelvic bone come from graves 204, 232 and 534 in Rajhrad (Staňa 2006, 64, 66, 89, fig. $18 ; 20 ; 44)$. With regard to insufficient information on the hierarchic grading of indicators of the then system of values, it is not correct to consider the above mentioned feature an expression of a lower social status of those people, although according to S. Hendrychová (2014, 156-163), poorer people living in the catchment area of the Great Moravian hillfort were buried at the necropolis of Rajhrad.

We come across similar problems when trying to specify the social importance of knives with tubular bone handles. Their economic value could have been lowered by less sophisticated design of the relevant bone which was limited to transverse separation of end parts. The comparative collection from seven graves from the territory of today's Moravia did not obtain less valuable parameters which would be considerably different from the 
environment with occurrence of knives with bone slabs. Nevertheless, most of them come from graves of adult women located at church cemeteries (Hochmanová-Vávrová 1962, 238, pl. XXI: 3; Hrubý 1955, pl. XXII: 2, 3; Kalousek 1971, 32, fig. 12; Macháćek et al. 2016, 248, pl. 7; 64: 2; 85; Marešová 1983, 81; Profantová 2003, 85, fig. 51: 3).

In the territory of Slovakia, we find bone knife handles mainly at burial grounds scattered in rural environment. Mainly adult men with max. average value parameters of find contexts were deposited in such graves (Chropovský 1957, 181, 182, pl. VIII: 8; Liptáková 1963, 228, fig. 10: 12; Točík 1971, 191, pl. LI: 9, 10; 1992, 134, fig. 81: 6, 8). Among the recorded finds, probably only the knife from grave 3 from Michal nad Žitavou calls more attention. A tubular part with circular cross-section originally probably used as a needle case was attached to its tang. Besides its corresponding size, it is suggested also by engraved motifs applied also on needle cases discovered in graves 40 and 119 in Vel'ký Grob (Chropovský 1957, 178, 187, 195, pl. VI: 20; XII: 13).

Judging by the exterior design, we can assume that simple production processes were applied in making other tubular knife handles, such as cutting and chipping. These were commonly used in the rural environment to make more general-purpose tools (Slivka 1984, 379). According to B. Kavánová (1995, 127-171) and R. Švecová (2000, 62-66), several shapes of awls, perforators, bone flatteners and needles were predominant.

In most previous cases, various motifs of engraved decoration occurred on the knives' bone handles. In the collection, simple and concentric patterns with a central point engraved with a compass engraver are predominant. They are most often concentrated in two or three parallel bands parallel with the knife's longer axis, covering the whole surface of bone slabs. On the other hand, they are sometimes only complementary decoration to another - more dominant - element. Many representatives belong to the universally applied motifs documented in the wider central European environment. In the territory of Slovakia, we can see it on bone and antler artefacts of different use from the Bronze Age and it was also very popular in the Late Iron Age, Roman period as well as the Great Migration period. Later, it occurs more or less frequently in the whole period of the Middle Ages and it was not forgotten in the Postmedieval period either. There are the youngest bone finds roughly dated to the Middle Ages and the Early Postmedieval period from the territory of Nitra. The bone handle of a knife from the excavations at Mostná ulica street with circles with central points applied on the head is an example (BřezinoválSamuel 2007, fig. 74: d). Besides this knife, a bone needle with concentric circles comes from this site (Březinovál Samuel 2007, fig. 73: c).

In the Early Middle Ages, we observe use of simple or concentric circles also in a different cultural environment. It is e.g. the Frankish environment represented by artefacts made of bones, ivory and antlers (Capelle 1968, 240). Related exemplars of handles also appear during the Carolingian period in the territory of the Upper and Lower Austria. B. Szóke (2019, 144, 145, pl. 20: 16; 21: 18; 32) monitors the occurrence of such artefacts in female burials from the end of the $8^{\text {th }}$ and the first half of the $9^{\text {th }} \mathrm{c}$. The studied circles are either the only decorative element or they can be combined with other motifs. Grave goods from the Hungarian burial ground in Sopronkőhida are another example. Slabs of long handles from graves 25, 59, 62 and 103 were decorated with one or more lines of circles (Török 1973, 13, pl. $8: 1,18 ; 13: 5,19 ; 14: 12,25 ; 22: 10)$. Iron knives with short narrow blades often documented in female burials indicate - according to B. Szóke (2014, 37, 41, fig. 26) - their use in a specialized activity carried out by the members of this gender.

A more concentrated occurrence of similar finds was recorded again in the $10^{\text {th }}-11^{\text {th }} \mathrm{c}$. in the agglomeration of Libice (Kaván 1958, 273, 274, pl. X: 5; Mařík 2009, 105, 123, 174, 262, pl. 78: 1). The studied motif remains popular in decoration of knives also in the High and Late Middle Ages. The knife handle decorated with concentric circles discovered in the late medieval settlement feature from Chlaba is not exceptional either (Zábojník 1980, 253, 254, fig. 149: 1) as well as the one from Wroclaw (WieczorekKańczura/Szajt 2018, 310, 311, 386, fig. 201, inv. no. 235/11; 258c). Numerous examples of knives decorated with the motif of simple or concentric circles from the $11^{\text {th }}-16^{\text {th }} \mathrm{c}$. are brought by a publication dealing with medieval and early postmedieval knives from the selected coastal areas of the North and Baltic seas (Holtmann 1993, 395, 396, fig. 130; 164).

The presented examples fully correspond with the above described opinions pointing to a wider territorial span and chronological frame of occurrence of the decorative element in question. It cannot be ignored that the obtained information is not considerably associated with the topic preferably solved in this article. In most cases, it is confirmed by the absent social stratification of finds as well as more accurate specification of frequency of relevant exemplars' occurrence in the relevant geographical time and space. Even from the territory of Slovakia, we cannot compare the limited number of known early medieval examples with their more massive presence during the Late Middle Ages and the Early Postmedieval period. 


\section{FINAL REFLECTIONS}

Knife handles consisting of two slabs complemented with decorative motifs discovered at two burial grounds in historical Nitra extended the extremely sporadic group of more luxurious exemplars made of bones and antlers recorded in the territory of Slovakia. The collection also includes a conical clarinet-type shawm made from a deer antler and discovered in grave 26 in Pobedim-Na laze (Vendtová 1969, 181, fig. 52: 11). Tubular cases used for storing loose or viscous substances and other miniature items were made of identical raw material (Kavánová 1995, 85, 86; Vignatiová 1992, 79). They also include e.g. the exemplars with octagonal cross-section from grave 128 in Smolenice (Dušek 1979, 369, 370, fig. 6: 8), from grave 28 at the municipality burial ground in Mužla-Čenkov-Vilmakert (Hanuliak/Kuzma 2015, 153, pl. LXI: 2) and from a residential pithouse 448 studied at the same site (Hanuliak/Kuzma/Šalkovský 1993, 32, pl. 149: 16).

The previously suggested circumstances do not provide persuasive arguments explaining the limited occurrence of more luxurious products made from bones and antlers. We cannot exclude the possibility that the reasons for this lie in the abundance of other ways to emphasise the above-average status of some individuals used in the Great Moravian period. This may also be the reason why there was no urgent need of more intense development of bone production. Therefore, domestic production was focused on easy modification of bones into working tools and more luxurious representatives were imported from continuously operating workshops. Even without a more detailed evaluation of the above mentioned representatives' provenance, it is sure that the artefacts from this collection would not have been made without a verified working procedure, a wide range of used tools, routine skills and softening of the material by cooking it in suitably concentrated solutions. Many of these components were summarized in a study by J. Kaván (1980), who re-evaluated and experimentally verified other scientists' opinions. In their point of view, it was in the well-known cases - a specialized production activity primarily done by members of certain families (Kavánová 1995, 250, 251; Švecová 2000, 84-88). Publication of the find contexts obtained from the so-called bone manufacture mentioned by B. Chropovský (1970, 164; 1975, 6, fig. 8) and studied at the site of Martinský vrch-Kasárne pod Zoborom would definitely help us confirm such production in the territory of historical Nitra. With regard to the chronological gap between both evaluated graves with the studied form of knives which is estimated to four-five decades, they are probably not products from the same workshop.

\section{BIBLIOGRAPHY}

Bednár/Fottová 2003 - P. Bednár/E. Fottová: Nitra-tržnica príspevok $\mathrm{k}$ poznaniu zázemia stredovekého mesta. Archaeologia historica 28, 2003, 303-315.

Březinová/Samuel 2007 - G. Březinová/M. Samuel a kolektív: „Tak čo, našli ste niečo?" Svedectvo archeológie o minulosti Mostnej ulice v Nitre. Nitra 2007.

Capelle 1968 - T. Capelle: Karolingischer Schmuck in der Tschechoslowakei. Slovenská archeológia 16, 1968, 229-244.

Chropovský 1957 - B. Chropovský: Slovanské pohrebisko z 9. stor. vo Vel'kom Grobe. Slovenská archeológia 5, 1957, 174-239.

Chropovský 1970 - B. Chropovský: Slovensko na úsvite dejín. Bratislava 1970.

Chropovský 1975 - B. Chropovský: Nitra. Archeologický výskum slovanských lokalit. III. medzinárodný kongres slovanskej archeológie, Bratislava 7.-14. september 1975. Bratislava 1975.

Dušek 1979 - S. Dušek: Vel'komoravské pohrebisko v Smoleniciach. Slovenská archeológia 27, 1979, 365-373.

Hanuliak 2004 - M. Hanuliak: Vel'komoravské pohrebiská. Pochovávanie v 9.-10. storočí na území Slovenska. Archaeologica Slovaca Monographiae. Studia 8. Nitra 2004.

Hanuliak 2019a - M. Hanuliak: Waffen und Kriegerausrüstung in großmährischen Gräbern auf dem Gebiet der Slowakei. In: L. Poláček/P. Kouřil (Hrsg.): Bewaffnung und Reiterausrüstung des 8. bis 10. Jahrhunderts in Mitteleuropa. Waffenform und Waffenbeigaben bei den mährischen Slawen und in den Nachbarländern. Internationale Tagungen in Mikulčice. Band 9. Brno 2019, 37-50.

Hanuliak 2019b - M. Hanuliak: Štruktúra vel'komoravského hradského mesta Nitrava na základe pochovávania. In: P. Jenčík/Z. Staneková (zost.): Hradiská - svedkovia dávnych čias II. Dolná Mariková 2019, 75-89.

Hanuliak/Chropovský 2019 - M. Hanuliak/B. Chropovský: Pohrebisko z 9. storočia v Nitre-Dolných Krškanoch. Slovenská archeológia 67, 2019, 287-365.

DOI: https://doi.org/10.31577/slovarch.2019.67.9

Hanuliak/Kuzma 2015 - M. Hanuliak/I. Kuzma: Mužla-Čenkov II. Osídlenie z 9.-13. storočia. Archaeologica Slovaca Monographiae. Studia 25. Nitra 2015.

Hanuliak/Kuzma/Šalkovský 1993 - M. Hanuliak/I. Kuzma/ P. Šalkovský: Mužla-Čenkov I. Osídlenie z 9.-12. storočia. Materialia Archaeologica Slovaca 10. Nitra 1993.

Hendrychová 2014 - S. Hendrychová: Velkomoravská pohřebiště v Rajhradě a Rajhradicích. Rigorózní práce. Univerzita Karlova v Praze. Filozofická fakulta. Ústav pro archeologii. Praha 2014. Online available at: https://www.academia.edu/40353527/Velkomoravsk \%C3\%A1_poh\%C5\%99ebi\%C5\%A1t\%C4\%9B_v_ Rajhrad\%C4\%9B_a_Rajhradic\%C3\%ADch 
Hochmanová-Vávrová 1962 - V. Hochmanová-Vávrová: Velkomoravské pohřebiště ve Starém Měste "Na valách“. Výzkum v letech 1957-1959. Časopis Moravského muzea 47, 1962, 201-256.

Holtmann 1993 - G. F. W. Holtmann: Untersuchung zu mittelalterlichen und frühneuzeitlichen Messern. Göttingen 1993.

Hrubý 1955 - V. Hrubý: Staré Město. Velkomoravsképohřebiště „Na valách". Monumenta Archaeologica III. Praha 1955.

Hrubý 1957 - V. Hrubý: Slovanské kostěné předměty a jejich výroba na Moravě. Památky archeologické 48, 1957, 118-212.

Kalousek 1971 - F. Kalousek: Břeclav - Pohansko I. Velkomoravské pohřebiště u kostela. Brno 1971.

Kaván 1958 - J. Kaván: O zpracování a výzdobě kosti u západních Slovanů v době hradištní. Vznik a počátky Slovanu 2, 1958, 253-285.

Kaván 1980 - J. Kaván: Technologie zpracování parohové a kostěné suroviny. Archeologické rozhledy 32, 1980, 280-304.

Kavánová 1995 - B. Kavánová: Knochen- und Geweihindustrie in Mikulčice. In: F. Daim/L. Poláček (Hrsg.): Studien zum Burgwall von Mikulčice I. Brno 1995, 113-378.

Liptáková 1963 - Z. Liptáková: Slovanské pohrebisko z X.-XI. storočia v Úlanoch nad Žitavou. Slovenská archeológia 11, 1963, 223-236.

Lukačka 2010 - J. Lukačka: Nitra. In: M. Štefánik/J. Lukačka (zost.): Lexikon stredovekých miest na Slovensku. Bratislava 2010, 283-291.

Macháček et al. 2016 - J. Macháček/P. Dresler/R. Přichystalová/V. Sládek: Břeclav-Pohansko VII. Kostelní pohřebiště na Severovýchodním předhradí. Brno 2016.

Marešová 1983 - K. Marešová: Uherské Hradiště-Sady. Staroslovanské pohřebiště na Horních Kotvicích. Brno 1983.

Mařík 2009 - J. Mařík: Libická sídelní aglomerace a její zázemí $v$ raném středověku. Dissertationes archaeologicae Brunenses/Pragensesque 7. Praha 2009.

Přichystalová/Kalová/Boberová 2019 - R. Přichystalová/K. Kalová/K. Boberová: Břeclav - Pohansko IX. Pohřební areály z Jižního předhradí (archeologicko-antropologická studie). Brno 2019

Profantová 2003 - N. Profantová: Mikulčice - pohřebiště u 6. kostela: Pokus o chronologické a sociální zhodnocení. In: N. Profantová/B. Kavánová: Mikulčice-pohřebiště u 6. a 12. kostela. Spisy Archeologického ústavu AV ČR Brno 22. Brno 2003.

Rejholcová 1995 - M. Rejholcová: Pohrebisko v Čakajovciach (9.-12. storočie). Analýza. Archaeologica Slovaca Monographiae. Fontes 15. Nitra 1995.

Slivka 1984 - M. Slivka: Parohová a kostená produkcia na Slovensku v období feudalizmu. Slovenská archeológia 32, 1984, 377-429.

Staňa 2006 - Č. Staňa: Velkomoravská pohřebiště v Rajhradě a Rajhradicích. Katalog. Spisy Archeologického ústavu AV ČR Brno 29. Brno 2006.

Švecová 2000 - R. Švecová: Nálezy kostenej a parohovej industrie z predvel'komoravských a vel'komoravských sídlisk na Pohansku pri Břeclavi do roku 1995. Sborník prací FF UK Brno, M5, 2000, 61-95.

Szóke 2014 - B. M. Szőke: The Carolingian age in the Carpathian Basin. Permanent exhibition of the Hungarian National Museum. Budapest 2014.

Szőke 2019 - B. M. Szőke: A Karoling-kor Pannóniában. Mosaburg Zalavár 1. Budapest 2019.

Točík 1971 - A. Točík: Flachgräberfelder aus dem IX. und X. Jahrhundert in der Südwestslowakei. Slovenská archeológia 19, 1971, 135-276.

Točík 1992 - A. Točík: Materiály k dejinám južného Slovenska v 7.-14. storočí. Študijné zvesti AÚ SAV 28, 1992, 5-248.

Török 1973 - G. Török: Sopronkőhida IX. századi temetője. Fontes Archaeologici Hungariae. Budapest 1973.

Vendtová 1969 - V. Vendtová: Slovanské osídlenie Pobedima a okolia. Slovenská archeológia 17, 1969, 119-224.

Vignatiová 1992 - J. Vignatiová: Břeclav - Pohansko II. Slovanské osídlení jižního předhradí. Spisy Masarykovy univerzity, Filozofická fakulta 291. Brno 1992.

Vondráková 1982 - M. Vondráková: Nitra-Dolné Krškany. Antropologický posudok slovanského pohrebiska. Dokumentácia AÚ SAV Nitra 9970/82. Nitra 1982. Unpublished.

Wieczorek-Kańczura/Szajt 2018 - K. Wieczorek-Kańczura/ J. Szajt: Noże, pochewki i okucia pochewek na noże. In: J. Piekalski/K. Wachowski (red.): Rytm rozwoju miasta na kulturowym pograniczu. Studium strefy placu Nowy Targ we Wroctawiu. Wratislavia Antiqua 23. Wroclaw 2018, 296-322.

Zábojník 1980 - J. Zábojník: Tretia sezóna výskumu v Chlabe. AVANS 1979, 1980, 253-255.

Manuscript accepted 29. 6. 2021

Text translated by Viera Tejbusová

Abstract translated by Lucia Nezvalová

PhDr. Milan Hanuliak, DrSc.

Archeologický ústav SAV

Akademická 2

SK - 94921 Nitra

milan.hanuliak@savba.sk

Mgr. Zuzana Poláková, PhD.

Archeologický ústav SAV

Akademická 2

SK - 94921 Nitra

zuzana.polakova@savba.sk 
